\title{
Roles of gangliosides in mouse embryogenesis and embryonic stem cell differentiation
}

\author{
Dong Hoon Kwak ${ }^{1}$, Byoung Boo Seo ${ }^{2}$, \\ Kyu Tae Chang ${ }^{3}$ and Young Kug Choo, \\ ${ }^{1}$ Department of Biological Science \\ College of Natural Sciences \\ Biotechnology Institute \\ Wonkwang University \\ Iksan 570-749, Korea \\ ${ }^{2}$ Department of Animal Resources \\ College of Life and Environmental Sciences \\ Daegu University \\ Gyeongsan 712-714, Korea \\ ${ }^{3}$ National Primate Research Center \\ Korea Research Institute of Bioscience and Biotechnology \\ Ochang 363-883, Korea \\ ${ }^{4}$ Corresponding author: Tel, +82-63-850-6087; \\ Fax, +82-63-857-8837; E-mail, ykchoo@ wonkwang.ac.kr \\ DOI 10.3858/emm.2011.43.7.048
}

Accepted 1 June 2011

Available Online 7 June 2011

Abbreviations: CNS, central nervous system; EBs, embryonic bodies; ES cells, embryonic stem cells; FSH, follicle-stimulation hormone; GSLs, glycosphingolipids; LH, luteinizing hormone; mES cells, mouse embryonic stem cells; NGF, neuronal growth factor; RA, retinoic acid; SSEA-1, stage-specific embryonic antigen-1; STZ, streptozotocin

\begin{abstract}
Gangliosides have been suggested to play important roles in various functions such as adhesion, cell differentiation, growth control, and signaling. Mouse follicular development, ovulation, and luteinization during the estrous cycle are regulated by several hormones and cell-cell interactions. In addition, spermatogenesis in seminiferous tubules of adult testes is also regulated by several hormones, including follicle-stimulating hormone (FSH) and luteinizing hormone (LH) and cell-cell interactions. The regulation of these processes by hormones and cell-cell interactions provides evidence for the importance of surface membrane components, including gangliosides. During preimplantation embryo development, a mammalian embryo undergoes a series of cleavage divisions whereby a zygote is converted into a blastocyst that is sufficiently competent to be implanted in the ma-
\end{abstract}

ternal uterus and continue its development. Mouse embryonic stem ( $\mathrm{mES}$ ) cells are pluripotent cells derived from mouse embryo, specifically, from the inner cell mass of blastocysts. Differentiated neuronal cells are derived from $\mathrm{mES}$ cells through the formation of embryonic bodies (EBs). EBs recapitulate many aspects of lineage-specific differentiation and temporal and spatial gene expression patterns during early embryogenesis. Previous studies on ganglioside expression during mouse embryonic development (including during in vitro fertilization, ovulation, spermatogenesis, and embryogenesis) reported that gangliosides were expressed in both undifferentiated and differentiated (or differentiating) mES cells. In this review, we summarize some of the advances in our understanding of the functional roles of gangliosides during the stages of mouse embryonic development, including ovulation, spermatogenesis, and embryogenesis, focusing on undifferentiated and differentiated $\mathrm{mES}$ cells (neuronal cells).

Keywords: cell differentiation; embryonic development; embryonic stem cells; gangliosides; ovulation; spermatogenesis

\section{Introduction}

Glycosphingolipids (GSLs) can be subdivided into neutral GSLs and acidic GSLs. Acidic GSLs containing sialic acid residue(s) in their carbohydrate moiety are referred to as gangliosides. Gangliosides are key signaling molecules in biological processes, including cellular adhesion and receptor signal transduction (Huwiler et al., 2000). They are widely found in the plasma membranes of all vertebrate tissues and are particularly abundant in the central nervous system (CNS) (Svennerholm, 1980; Yu et al., 2004). Complement-induced neuron degeneration and the phenotypes of genetically engineered mice lacking gangliosides, i.e., mice with a double knockout in GM2/GD2 synthase and GD3 synthase (Ohmi et al., 2009), clearly demonstrate that gangliosides have a wide variety of functional roles (Proia, 2003). Clinically, GSLs play important roles in the pathogenesis of certain neuropathies such as Guillain-Barré syndrome, a disorder caused by an autoimmune response to cell surface gangliosides (Kaida et al., 2009), and 


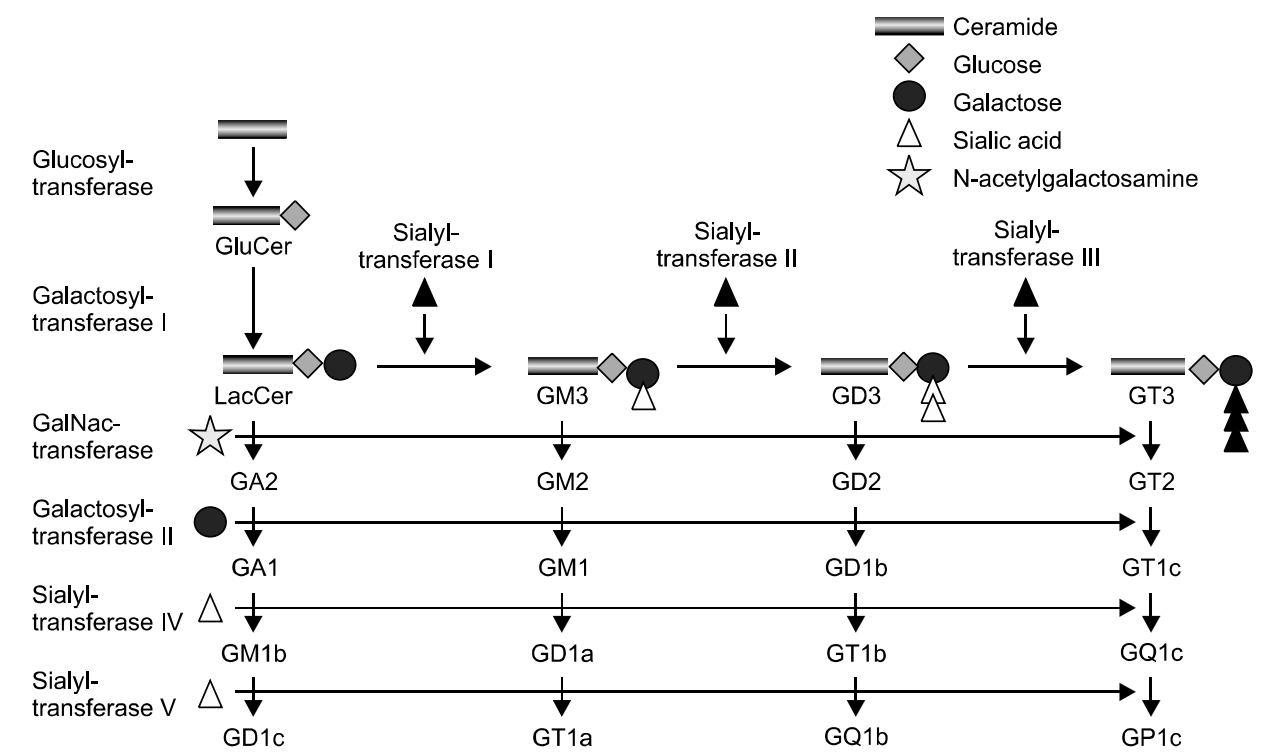

Figure 1. Metabolic pathways of ganglioside synthesis involving transferase enzymes.

autosomal recessive infantile-onset symptomatic epilepsy syndrome, a disorder caused by a nonsense mutation in GM3 synthase (Simpson et al., 2004). Recently, it has also been suggested that gangliosides initiate the aggregation of amyloid- $\beta$ peptide and contribute to the onset of Alzheimer's disease (Matsuzaki et al., 2010).

The morphology of mammalian ovaries dramatically changes during the estrous cycle; throughout corpus luteum formation, and in all stages of follicular development, including the formation of primary, secondary, and Graafian follicle (Erickson, 1978). In the murine ovary, oocytes are shed from a mature Graafian follicle during the process of ovarian maturation at a precise time, after the onset of a LH surge. One function of the corpus luteum is to secrete progesterone, a hormone that is important for controlling the length of the estrous cycle and maintaining pregnancy, if implantation and fertilization occur (Galway et al., 1990). Follicular development, ovulation, and luteinization are regulated by several hormones and cell-cell interactions, which indicate the importance of surface membrane components, including gangliosides, during the estrous cycle. Nagai and Hoshi (1975) showed that sea urchin eggs have very high ganglioside content, and they demonstrated the euplastic distribution of gangliosides and the changes that occur after fertilization.

Spermatogenesis has been studied extensively in mammalian testis (Fawcett, 1975). Mammalian spermatozoa are produced by a process known as spermatogenesis that occurs in the seminiferous tubules, coiled tubes that are located in the testes.
These seminiferous tubules contain 2 types of somatic cells, myoid or smooth muscle-like cells and Sertoli cells, as well as 5 other types of germ cells: spermatogonia, primary and secondary spermatocytes, spermatids, and spermatozoa. Spermatogenesis in the seminiferous tubules of adult testes is regulated by several hormones, including $\mathrm{FSH}$ and $\mathrm{LH}$, and by cell-cell interactions.

Embryonic stem (ES) cells are derived from the inner cell mass of mammalian embryos and are defined as undifferentiated cells endowed with a high potential for proliferation and the capacity to differentiate into progeny through self-renewal with the retention of pluripotency or multipotency (Smith, 2001). This self-renewal capacity is regulated by a set of transcription factors including Oct4, Nanog, and Sox2 (Niwa, 2007). Recently, genome-wide chromatin immunoprecipitation (ChIP) analyses in mouse ES (mES) cells have identified the genomic binding sites for Oct 4 and a number of other mES cell transcription factors (Chen et al., 2008; Kim et al., 2008b; Sridharan et al., 2009). ES cells are important not only biologically but also clinically. These cells can act as reservoirs for the formation of tissues and organs during development and for the replacement of cells lost during normal cell turnover that occurs in adulthood. They can also be used in cell replacement therapy for a variety of disorders and injuries. Cell surface molecules that can be used as markers for the identification and isolation of stem cells are essential for basic biological study and clinical use of ES cells. Glycolipids on the cell surface can serve as marker molecules (Yanagisawa and Yu, 2007). To date, many 
Table 1. Gangliosides expression in the Spermatogenesis, Ovarian maturation and Uterus of mousse

\begin{tabular}{|c|c|c|c|}
\hline $\begin{array}{l}\text { Developmental } \\
\text { stages }\end{array}$ & Cells & Gangliosides & References \\
\hline & Sertoliccells & GM3 & $\begin{array}{l}\text { Stern et al., } 2000 \\
\text { Jung et al., } 2001\end{array}$ \\
\hline & Sperm & GM1 & Trevino et al., 2001 \\
\hline & & & Shadan et al., 2004 \\
\hline Spermatos & & & Selevaraj et al., 2006 \\
\hline & Primary follicle & GM3, GM1, GD1a, GD1b, GT1b,GM2, GD3 & Hottori \& Horiuch, 1992 \\
\hline & & & Choo et al., 1995, 1999 \\
\hline & & & Kim et al., 2006 \\
\hline & & & Kwak et al., 2003 \\
\hline & Secondary follicle & GM3, GM1, GD1a, GD1b,GD3,GM2 & Choo et al., 1995, 1999 \\
\hline \multirow{5}{*}{ Ovary maturation } & & & Kim et al., 2006 \\
\hline & & & Kwak et al., 2003 \\
\hline & Graafian follicle & GM3, GM1, GM2, GT1b,GD1a, & Choo et al., 1995, 1999 \\
\hline & & & Kim et al., 2006 \\
\hline & & & Kwak et al., 2003 \\
\hline \multirow[t]{8}{*}{ Uterus } & Uterus & GT1b, GD1a, GM1, GD1b & Kim et al., 2006 \\
\hline & Fertilization & GM3 & Kwak et al., 2003 \\
\hline & 2-cell & GM3, GT1b & Kwak et al., 2003 \\
\hline & & & Kim et al., 2008a \\
\hline & 4-cell & GM3, GT1b & Kwak et al., 2003 \\
\hline & & & Kim et al., 2008a \\
\hline & Morula(32-cell) & GM3, GT1b & Kwak et al., 2003 \\
\hline & & & Kim et al., 2008a \\
\hline \multirow[t]{2}{*}{ Early embryogenesis } & Blastocyst & GM3, GT1b & Kwak et al., 2003 \\
\hline & & & Kim et al., 2008a \\
\hline & E9 & GM3, GM1,GD1a, GT1b & Ji et al., 2000 \\
\hline & E11 & GM3, GM1, GD1a, GM2, GT1b, GD3 & Ji et al., 2000 \\
\hline & & & Yu et al., 1998 \\
\hline & E12 & GD3, GM3, GT1b, GM2, GM1, GD1a, GD1b, GQ1b & Ji et al., 2000 \\
\hline & & & Yu et al., 1998 \\
\hline & & & Bouvier\& Seyfried, 1989 \\
\hline & E13 & GD3, GM3, GT1b, GM2, GM1, GD1a, GD1b, GQ1b & Ji et al., 2000 \\
\hline & & & Yu et al., 1988 \\
\hline & E14 & GD3, GM3, GM2, GM1, GD1a, GT1b & Nakamukote et al., 2007 \\
\hline & E15 & GM3,GM1,GD1a,GD3 & $\begin{array}{l}\text { Bouvier \& Seytried, } 1989 \\
\text { Ji et al., } 2000\end{array}$ \\
\hline Late embryogenesis & & & Yu et al., 1988 \\
\hline & E16 & GD1a, GD3, GM3 & Nakamukote et al., 2007 \\
\hline
\end{tabular}

glycolipids expressed on pluripotent stem cells, multipotent stem cells, and cancer stem cells have been identified by biochemical and immunological analyses. Some of these cells have been shown to be excellent stem cell biomarkers. In this review, we will describe the gangliosides expressed during mouse ovulation, spermatogenesis, and embryogenesis, as well as in stem cells, and discuss their availability as biomarkers for the identification of $\mathrm{mES}$ cells and their differentiation. Figure 1 shows the metabolic pathways for ganglioside production in the mouse. A complete list of gangliosides expressed in spermatogenesis, ovarian maturation, and embryogenesis is shown in Table 1. The various gangliosides expressed in germ cells of the mouse ovary are given in Table 2. Ganglioside expression in $\mathrm{mES}$ cells, embryonic bodies (EBs) and differentiated neuronal cells of mES cells is described in Table 3.

\section{Gangliosides}

Gangliosides, sialic acid-containing GSLs, are believed 
Table 2. The expression of gangliosides in germ cells of the mouse ovary

\begin{tabular}{|c|c|c|c|c|}
\hline & Follicle & Germ cells & Gangliosides & References \\
\hline \multirow[t]{8}{*}{ Ovarian maturation } & Primary & Interstitial cells & GM3, GM1, GD1a, GD1b & $\begin{array}{l}\text { Choo et al., 1995, } 1999 \\
\text { Kim et al., } 2006 \\
\text { Kwak et al., } 2003\end{array}$ \\
\hline & & Theca cells & GM3, GM1, GD1a & $\begin{array}{l}\text { Choo et al., 1995, } 1999 \\
\text { Kim et al., } 2006 \\
\text { Kwak et al., } 2003\end{array}$ \\
\hline & & Granulosa cells & GM3 & $\begin{array}{l}\text { Choo et al., 1995, } 1999 \\
\text { Kim et al., } 2006\end{array}$ \\
\hline & & Oocytes & GM3 (diabetic mouse) GD1a & $\begin{array}{l}\text { Choo et al., 1995, } 1999 \\
\text { Kwak et al., } 2003\end{array}$ \\
\hline & Secondary & Theca cells & GM3, GM1, GD1a & $\begin{array}{l}\text { Choo et al., 1995, } 1999 \\
\text { Kim et al., } 2006 \\
\text { Kwak et al., } 2003\end{array}$ \\
\hline & & $\begin{array}{l}\text { Granulosa cells } \\
\text { Oocytes }\end{array}$ & & \\
\hline & Graafian & Theca cells & GM3, GM1, GD1a & $\begin{array}{l}\text { Choo et al., 1995, } 1999 \\
\text { Kim et al., } 2006 \\
\text { Kwak et al., } 2003\end{array}$ \\
\hline & & Granulosa cells & GM3 & $\begin{array}{l}\text { Choo et al., 1995, } 1999 \\
\text { Kim et al., } 2006\end{array}$ \\
\hline
\end{tabular}

to be involved in the development, differentiation, and function of the nervous system in vertebrates (Schengrund, 1990). While most gangliosides reside in the outer leaflet of the cell membrane, where they are crucial for the maintenance of membrane structure and organization, a small percentage $(10 \%)$ is located in the mitochondria and endoplasmic reticulum (ER). The biosynthesis of gangliosides occurs in the ER and the Golgi complex and is mediated by the action of membrane-bound glycosyltransferases and sialyltransferases, which catalyze the transfer of sugar nucleotide donors to sphingolipid acceptors (Huwiler et al., 2000; Kolter et al., 2002). Complex gangliosides that are more glycosylated are built by the stepwise addition of sugar nucleotides to LacCer. In particular, specific sialyltransferases generate viability gangliosides; the predominant gangliosides are simple, like GM3 and GD3, while the more complex ones are GM1, GD1a, GD1b, and GT1b (Figure 1). The diverse

Table 3. The expression of gangliosides in mES cells, Ebs, and differentiated neuronal cells

\begin{tabular}{|c|c|c|c|}
\hline & Mouse embryonic stem cells (mEScells) & Embryonic body (EBs) & Neuronal cells \\
\hline & $\begin{array}{l}\text { Blastocyst-derived } \\
\text { Undifferentiated mouse stem cells }\end{array}$ & $\begin{array}{l}\text { Differentiated embryonic body from } \\
\text { mouse embryonic stem cells }\end{array}$ & $\begin{array}{l}\text { Differentiated Neuronal cells from } \\
\text { mouse embryonic body (mES cells) } \\
\text { by retinoic acid (RA) }\end{array}$ \\
\hline Gangliosides & GM3, GM1, GD3 & GM3, GD3, GT1b, GM2 & GT1b, GM1, GD3, GD1a, GQ1b, GM3 \\
\hline References & $\begin{array}{l}\text { Kwak et al., } 2006 \\
\text { Lee et al., } 2007\end{array}$ & $\begin{array}{l}\text { Kwak et al., } 2006 \\
\text { Lee et al., } 2007 \\
\text { Jung et al., } 2009\end{array}$ & $\begin{array}{l}\text { Ferrari et al., } 1983 \\
\text { Kawai et al., } 1998 \\
\text { Osanai et al., } 2003 \\
\text { Kwak et al., } 2006 \\
\text { Lee et al., } 2007 \\
\text { Jung et al., } 2009\end{array}$ \\
\hline
\end{tabular}


and heterogeneous molecular structures of ganglioside carbohydrate chains are important characteristics. Ganglio-series GSLs that have 0,1,2, and 3 sialic acid residue(s) linked to the inner galactose residues in their carbohydrate moieties are classified as a-, $b$-, and c-series gangliosides. The gangliosides that have a NeuAca2-6GalNAc structure are referred to as a-series gangliosides (Nakamura et al., 1988). Gangliosides play important roles in a large variety of biological processes, including cell-cell interaction, adhesion, cell differentiation, growth control, receptor function, and induction of inflammatory responses (Ji et al., 1999; Lee et al., 2010). Ganglioside GM3 has the simplest carbohydrate structure and is known to be involved in signal transduction (Hakomori et al., 1998), modulation of cell proliferation (Hakomori, 1990), induction of HL-60 differentiation (Nojiri et al., 1986), maintenance of fibroblast morphology, and integrin- mediated cell adhesion (Kojima et al., 1996). Studies have reported that there are drastic changes in the expression patterns and levels of gangliosides during embryonic development. The changes occur in the gangliosides themselves (Yu et al., 1988; Bouvier and Seyfried, 1989), as well as in the glycosyltransferases and glycosidases (Ishii et al., 2007) that regulate ganglioside synthesis. Other recent studies based on analyses in genetically engineered animals, have demonstrated that gangliosides mainly play roles in the maintenance and repair of nervous tissues (Furukawa et al., 2007; Kittaka et al., 2008). This implies that gangliosides can be useful as stage-specific marker molecules in developing cells, including embryogenesis and stem cells (Yanagisawa and Yu, 2007).

\section{Gangliosides in mouse ovulation and spermatogenesis}

Gangliosides, which are GSLs with 1 or more sialic acid residues, are cell-type specific and expressed mainly in the plasma membrane (Kim et al., 2006). Gangliosides are a large group of sialized GSLs, which are widely expressed in mammalian cells (Furukawa, 1998), that function in cell differentiation, cell growth, and transmembrane signaling (Hakomori, 1981; Choo, 1999). During preimplantation embryo development, the mouse embryo undergoes a series of cleavage divisions, whereby a zygote is converted to a blastocyst that is sufficiently competent for uterine implantation and continued development (Table 1). The ganglioside GM3 was found to be distributed predominantly in the Sertoli cells of murine seminiferous tubules (Jung et al., 2001). The germ cells of female mice are known to express GM1 in the cytoplasm (Kanai et al., 1990). $\mathrm{FSH}$ and insulin together were reported to enhance GM3 production by cultured immature granulosa cells, while LH expression in granulosa cells was reported to be decreased by the addition of GM3 (Hattori and Horiuchi, 1992). Choo et al. (1995) observed that theca cells of primary follicles in adult rat ovaries were positive, and that granulosa cells of Graafian follicles express GM3 just before ovulation (Tables 1 and 2). GM1, GM3, GD1a, and GD1b were found to be expressed in interstitial cells during ovarian maturation in mouse (Choo et al., 1995, 1999; Kim et al., 2006, Table 2). Kim et al. (2008a) investigated whether the expression of ganglioside GT1b was regulated during early embryonic development or the survival of frozenthawed embryos (Tables 1 and 2). Kwak et al. (2003) reported that GM3 expression was increased in diabetic $d b / d b$ mice during ovarian maturation (in primary and Graafian follicle). Mouse ovaries contain at least 5 different ganglioside components, including GM3, GM1, GD1a, and GT1b, and the uteruses of diabetic mice exhibited significant changes in the expression of major gangliosides. For example, in the uteruses of mice with streptozotocin (STZ)-induced diabetes, the expression of gangliosides such as GD1a and GT1b was reduced as expected; however, other gangliosides, including GM1 and GM2, were increased, as was GD3 expression (Kim et al., 2006). In contrast, in the uteruses of $d b / d b$ diabetic mice there was a significant increase in gangliosides, including GM1 and GD1a, and a significant increase in GD3 expression (Kim et al., 2006). Expression of ganglioside GT1b gradually increased during embryogenesis, but was not present in TUNELpositive, apoptotic embryos (Fujino et al., 1996).

Several studies have previously reported on the localization of GM1 in sperm; however, the results vary widely between and within species (Table 1). For example, in mouse, it has been suggested that GM1 localizes to the testes and that this localization does not change with capacitation (Trevino et al., 2001). In another study, GM1 was localized to the midpiece, and then moved to the head during capacitation (Shadan et al., 2004). The localization and movement of GM1 in murine sperm is important for several reasons (Table 1). For example, it provides evidence for the existence of membrane sub-domains in living cells, which is still a matter of some controversy (Munro, 2003). Standing in contrast to reports on the segregation of GM1 in live sperm (Selvaraj et al., 2006) are studies suggesting that there is no barrier to the lateral diffusion of lipids in mature spermatozoa (Mackie et al., 2001). 


\section{Gangliosides in mouse embryonic development}

In one study using diabetic mice, GM3 expression decreased during early embryonic development, including during in vitro fertilization and early embryogenesis (morula and blastocyst) (Kwak et al., 2003, Table 1). However, in general, synthesis of the hemato-series gangliosides GM3 and GD3 predominates during early embryogenesis of vertebrate animals, whereas the synthesis of the more complex gangliosides, such as GM1, GD1a, GD1b, and GT1b, predominates at later embryogenic stages (Yu et al., 1988; Comiskey and Warner, 2007). Ganglioside GM3 was synthesized by mST3GalV, and the expression and regulation of mST3GalV (CMP-NeuAc: lactosylceramide alpha-2, 3-sialyltransferase) activity is central to the production of almost all gangliosides. Spatial and temporal expression of mST3GalV mRNA (GM3) during mouse embryogenesis [on embryonic (E) days E9, E11, $\mathrm{E} 13$, and E15] was demonstrated by in situ hybridization with digoxigenin-labeled RNA probes ( $\mathrm{Ji}$ et al., 2000, Table 1). All tissue samples obtained on $\mathrm{E} 9$ and E11 were observed to have the same level of mST3GalV mRNA expression. On E13, mST3GalV mRNA was expressed in various neural and non-neural tissues and in the telencephalon, while on E15, strong expression of mST3Gal $V$ was observed in the liver (Ji et al., 2000). Bouvier and Seyfried (1989) observed that the predominant gangliosides in E12 mouse embryos were GD3 (51\% of total sialic distribution), GM3 (19\%), and GT1b (9.6\%); other gangliosides occurred in much lower amounts (GM2 (2.6\%), GM1 (1.6\%), GD1a (3.7\%), GD1b (6.3\%), and GQ1b (4.5\%)). Similar distributions were observed in both neural and non-neural embryonic structures, suggesting that undifferentiated embryonic cells in mice express GM3 and GD3 as the major ganglioside species (Bouvier and Seyfried, 1989). However, little is known about the expression of GT1b in preimplantation embryos. Ngamukote et al. (2007) reported that GD3 was a predominant ganglioside in $\mathrm{E} 12$ and $\mathrm{E} 14$ brains during embryogenesis. After $\mathrm{E} 16$, the concentration of GD3 and GM3 markedly decreased, and the concentration of a-series gangliosides, including GD1a, increased (Ngamukote et al., 2007). Yamamoto and Mohanan (2003) reported that ganglioside $\mathrm{GT} 1 \mathrm{~b}$ inhibits mitochondrial DNA damage in the brain during embryonic development. GD3-expressing cells sorted from embryonic, postnatal, and adult mouse brains were shown to have high proliferative potential, the ability to self-renew, marker expression, and multipotency for differentiation into neurons, astrocytes, or oligodendrocytes.

\section{Gangliosides in mouse embryonic stem cells}

ES cells are pluripotent cells that are generated from the inner cell mass of blastocysts (Liu et al., 2006). When mES cells are cultured with mouse embryonic fibroblasts and feeder cells, they proliferate indefinitely and retain the potential to differentiate into various lineages of all 3 primary germ layers (Martin, 1981). The stage-specific embryonic antigen-1 (SSEA-1) is the most wellknown (Muramatsu and Muramatsu, 2004). The epitope of this antibody was later determined to be Lewis X antigen (Gooi et al., 1981), and it is carried by glycoproteins and by ganglio-, globo-, neolacto-, and lacto-series glycolipids ( $\mathrm{Yu}$ and Yanagisawa, 2007). Survival of differentiated stem cells depends on the inhibition of the ganglioside biosynthesis (Liour and Yu, 2002). On the other hand, some GSLs, including gangliosides, have been biochemically detected in mES cells. In E14 mES cells, small amounts of a-series gangliosides, such as GM3, GM1, and GD1a, were identified by thin-layer chromatography (Kimber et al., 1993). Differentiated cells derived from E14 ES cells expressed larger amounts of gangliosides than undifferentiated mES cells; a significant amount of GalNAc-GD1a was expressed in the differentiated cells. In TC-1 mES cells, only glucosylceramide and lactosylceramide were detected (Yamashita et al., 1999). Previously studies have demonstrated that b-series gangliosides are important in neurogenesis (Okada et al., 2002) and are specifically expressed during the differentiation of mES cells into neuronal cells (Kwak et al., 2006). In mES cells, GM1, GM3, and GD3 were found (Kwak et al., 2006; Lee et al., 2007, Table 3). Furthermore, GM3, GT1b, and GD3 were found in the EBs of $\mathrm{J} 1 \mathrm{mES}$ cells (Kwak et al., 2006; Lee et al., 2007; Jung et al., 2009, Table 3). These bseries gangliosides, such as GD3, GM1, and GT1b, can serve as differentiation markers of mES cells. It is not clear why the gangliosides that were detected in mES cells differed considerably in these studies. The functional roles of gangliosides in pluripotent stem cells have been suggested by the analysis of glucosylceramide synthase-knockout $\mathrm{mES}$ cells that lack all glucosylceramide-based gangliosides (Yamashita et al., 1999)., When glucosylceramide synthase-knockout mES cells were injected into mice, teratomas were formed, which were similar to those formed by injection with wild-type mES cells. However, in the glucosylceramide synthase-knockout teratomas, there 
were no well-differentiated cells, such as cartilage, bone, smooth muscle, and glandular tissue cells, which were found in the wild-type mES cell-derived teratomas. This result indicates that gangliosides play an important role in embryonic development (Takamiya et al., 1996; Muramatsu and Muramatsu, 2004).

\section{Gangliosides in neuronal cell differentiation from mouse embryonic stem cells}

Generating differentiated cell types from mES cells occurs through the formation of EBs. EBs recapitulate many aspects of lineage-specific differentiation and temporal and spatial gene expression patterns in early embryogenesis (Leahy et al., 1999). Expression of GM3, GM2, and GD3 was detected in EBs $(4+)$ regardless of daunorubicin (DNR) treatment (Lee et al., 2007). Neuronal cells differentiated from the $\mathrm{J} 1 \mathrm{mES}$ cells expressed GM3 after 6 days and expressed GT1b in addition to GM1 after 9 days (Kwak et al., 2006). It was reported that expression of neuronal cell markers and gangliosides were highly associated with neurite formation in a neuroblastoma cell culture (Simons and Toomre, 2000). In contrast, when b-series gangliosides were blocked, neuronal differentiation from mES cells was unaffected (Furukawa et al., 2001). An increase in the ratio of a-series to b-series gangliosides occurs during the period of rapid axonal growth (Kawai et al., 1998). Finally, the expression of ganglioside GD3 synthase is specifically induced during neural differentiation from embryonic carcinoma P19 cells (Osanai et al., 1997). Treatment with gangliosides induced neuronal growth factor (NGF) activity in a rat neuronal PC12 cell line, and subsequently induced neurite formation (Ferrari et al., 1983). The expression of gangliosides was also responsible for the induction of neurite outgrowth in mouse neuroblastoma cells (Uemura et al., 1991). In mES cells, the expression of gangliosides was enhanced during retinoic acid (RA)-induced neural differentiation (Osanai et al., 2003). Exogenous addition of ganglioside GQ1b induced formation of neurites in neuroblastoma cells (Jung et al., 2009). Induction of GD3 synthase in neuroblastoma cells also resulted in increased expression of cell differentiation with formation of neurites (Rosner, 1998). The absence of gangliosides (3 b-series), such as GD3, GD1b, and GT1b, caused by the disruption of GD3 synthase did not affect RA-induced neural differentiation in mES cells (Kawai et al., 1998, Table 3). Lack of a-series gangliosides in GM2 knockout mice caused only subtle abnormalities in the developing nervous system (Takamiya et al., 1996). Gangliosides such as GD3, GT1b, and GQ1b changed during neural differentiation, and were enhanced upon RA-induced neural differentiation in mES cells (Osanai et al., 2003). In earlier studies, it was suggested that gangliosides play a pivotal role in neuronal differentiation (Hakomori, 1990). For example, ganglioside GM1 is widely distributed throughout the peripheral nervous system and plays regulatory roles during the neurogenesis and regeneration of injured peripheral nerves, whereas ganglioside GT1b is expressed in the brain synapses (Kotani et al., 1993). Treatment of neurons with ganglioside GT1b for 3 days markedly enhances actin-rich dendrite generation (Vinson et al., 2001). These reports demonstrate the important role of gangliosides $\mathrm{GM} 3, \mathrm{GM} 1$, and $\mathrm{GT} 1 \mathrm{~b}$ in neurogenesis.

\section{Conclusion}

There is no doubt that gangliosides are worthy of further study in both embryonic development and for the clinical application of mES cells. Gangliosides have been shown to be useful marker molecules for embryonic developmental stages and $\mathrm{mES}$ cell sorting. The identification of gangliosides, particularly those located on the plasma membrane, is becoming increasingly important due to their role in embryonic development and in the classification of specific populations of mES cells. As described above, specific gangliosides were detected at each embryonic developmental stage in mouse, including germ cells in testes, follicular maturation in ovaries, spermatogenesis, fertilization, embryogenesis, and in undifferentiated and differentiated mES cells. Additional aspects of the functional roles of gangliosides during cellular differentiation and proliferation remain to be explored. Such information will undoubtedly stimulate progress in the understanding of embryonic development and the development of stem cell-based therapeutic strategies for a variety of tissue damage conditions and degenerative diseases. Further identification of the gangliosides in embryonic development and stem cells should thoroughly characterize the expression of marker gangliosides and contribute to progress in the basic research and clinical applications in developmental biology and stem cell therapy.

\section{Acknowledgements}

This study was supported by a grant from the National 
Research Foundation (2011-0002208 and 2010-0022316) and a research grant from the Ministry of Education, Science and Technology (KGC5401011), Republic of Korea.

\section{References}

Bouvier JD, Seyfried TN. Ganglioside composition of normal and mutant mouse embryos. J Neurochem 1989;52:460-6

Chen X, Xu H, Yuan P, Fang F, Huss M, Vega VB, Wong E, Orlov YL, Zhang W, Jiang J. Integration of external signaling pathways with the core transcriptional network in embryonic stem cells. Cell 2008;133:1106-17

Choo YK, Chiba K, Tai T, Ogiso M, Hoshi M. Differential distribution of gangliosides in adult rat ovary during the oestrous cycle. Glycobiology 1995;5:299-309

Choo YK. Distribution of ganglioside GM3 in the rat ovary after gonadotropin stimulation. Mol Cells 1999;9:365-75

Comiskey M, Warner CM. Spatio-temporal localization of membrane lipid rafts in mouse oocytes and cleaving preimplantation embryos. Dev Biol 2007;303:727-39

Erickson GF. Normal ovarian function. Clin Obstet Gynecol 1978;21:31-52

Fawcett DW. The mammalian spermatozoon. Dev Biol 1975;44:394-436

Ferrari G, Fabris M, Gorio A. Gangliosides enhance neurite outgrowth in PC12 cells. Brain Res 1983;284:215-21

Fujino Y, Ozaki K, Yamamasu S, Ito F, Matsuoka I, Hayashi E, Nakamura H, Ogita S, Sato E, Inoue M. DNA fragmentation of oocytes in aged mice. Hum Reprod 1996; $11: 1480-3$

Furukawa K, Tajima O, Okuda T, Tokuda N, Furukawa K Knockout mice and glycolipids. In Comprehensive Glycoscience from Chemistry to Systems Biology, 2007, 149-57

Furukawa K, Takamiya K, Okada M, Inoue M, Fukumoto S. Novel functions of complex carbohydrates elucidated by the mutant mice of glycosyltransferase genes. Biochim Biophys Acta 2001;1525:1-12

Furukawa K. [Study on the functions of glycoprotein sugar chains in mammalian development: functions and expression of the beta 1-4 linked galactose residues]. Tanpakushitsu Kakusan Koso 1998;43:2309-17

Galway AB, Lapolt PS, Tsafriri A, Dargan CM, Boime I, Hsueh AJ. Recombinant follicle-stimulating hormone induces ovulation and tissue plasminogen activator expression in hypophysectomized rats. Endocrinology 1990;127:3023-8

Gooi HC, Feizi T, Kapadia A, Knowles BB, Solter D, Evans MJ. Stage-specific embryonic antigen involves alpha 1 goes to 3 fucosylated type 2 blood group chains. Nature 1981; 292:156-8

Hakomori S. Glycosphingolipids in cellular interaction, differentiation, and oncogenesis. Annu Rev Biochem 1981;50:733-64

Hakomori S. Bifunctional role of glycosphingolipids. Modulators for transmembrane signaling and mediators for cellular interactions. J Biol Chem 1990;265:18713-6

Hakomori S, Handa K, Iwabuchi K, Yamamura S, Prinetti A. New insights in glycosphingolipid function: "glycosignaling domain," a cell surface assembly of glycosphingolipids with signal transducer molecules, involved in cell adhesion coupled with signaling. Glycobiology 1998;8:xi-xix

Hattori M, Horiuchi R. Biphasic effects of exogenous ganglioside GM3 on follicle-stimulating hormone-dependent expression of luteinizing hormone receptor in cultured granulosa cells. Mol Cell Endocrinol 1992;88:47-54

Huwiler A, Kolter T, Pfeilschifter J, Sandhoff K. Physiology and pathophysiology of sphingolipid metabolism and signaling. Biochim Biophys Acta 2000;1485:63-99

Ishii A, Ikeda T, Hitoshi S, Fujimoto I, Torii T, Sakuma K, Nakakita S, Hase S, Ikenaka K. Developmental changes in the expression of glycogenes and the content of $\mathrm{N}$-glycans in the mouse cerebral cortex. Glycobiology 2007;17:261-76

Ji MY, Lee YC, Do S 2nd, Nam SY, Jung KY, Kim HM, Park LK, Choo YK. Developmental patterns of mST3GalV mRNA expression in the mouse: in situ hybridization using DIG-labeled RNA probes. Arch Pharm Res 2000;23:525-30

Ji MY, Lee YC, Kim KS, Cho JW, Jung KY, Kim CH, Choo YK. Developmental patterns of GalBeta1,3(4)GlcNAc alpha2,3sialyltransferase (ST3Gal III) expression in the mouse: in situ hybridization using DIG-labeled RNA probes. Arch Pharm Res 1999;22:243-8

Jung JU, Ko K, Lee DH, Chang KT, Choo YK. The roles of glycosphingolipids in the proliferation and neural differentiation of mouse embryonic stem cells. Exp Mol Med 2009;41:935-45

Jung KY, Kim BH, Hwang MR, Cho JR, Kim HM, Lee YC, Kim $\mathrm{CH}$, Kim JK, Kim BJ, Choo YK. Differential distribution of ganglioside GM3 in seminiferous tubule and epididymis of adult rats. Arch Pharm Res 2001;24:360-6

Kaida K, Ariga T, Yu RK. Antiganglioside antibodies and their pathophysiological effects on Guillain-Barre syndrome and related disorders--a review. Glycobiology 2009;19:676-92

Kanai Y, Kawakami H, Takata K, Kurohmaru M, Hayashi Y, Nishida T, Hirano H. Localization of Forssman glycolipid and GM1 ganglioside intracellularly and on the surface of germ cells during fetal testicular and ovarian development of mice. Histochemistry 1990;94:561-8

Kawai H, Sango K, Mullin KA, Proia RL. Embryonic stem cells with a disrupted GD3 synthase gene undergo neuronal differentiation in the absence of b-series gangliosides. J Bio Chem 1998;273:19634-8

Kim BH, Jung JU, Ko K, Kim WS, Kim SM, Ryu JS, Jin JW, Yang HJ, Kim JS, Kwon HC, Nam SY, Kwak DH, Park YI, Koo DB, Choo YK. Expression of ganglioside GT1b in mouse embryos at different developmental stages after cryopreservation. Arch Pharm Res 2008a;31:88-95

Kim J, Chu J, Shen X, Wang J, Orkin SH. An extended transcriptional network for pluripotency of embryonic stem cells. Cell 2008b;132:1049-61

Kim SM, Kwak DH, Jung JU, Lee DH, Lee S, Jung KY, Do SI, Choo YK. Differential expression of gangliosides in the ovary 
and uterus of streptozotocin-induced and $\mathrm{db} / \mathrm{db}$ diabetic mice. Arch Pharm Res 2006;29:666-76

Kimber SJ, Brown DG, Pahlsson P, Nilsson B. Carbohydrate antigen expression in murine embryonic stem cells and embryos. II. Sialylated antigens and glycolipid analysis. Histochem J 1993;25:628-41

Kittaka D, Itoh M, Kondo Y, Fukumoto S, Urano T, Tajima O, Furukawa K, Furukawa K. Impaired hypoglossal nerve regeneration in complex ganglioside-lacking mutant mice: down-regulation of neurotrophic factors and receptors as possible mechanisms. Glycobiology 2008;18:509-16

Kojima N, Kono M, Yoshida Y, Tachida Y, Nakafuku M, Tsuji $\mathrm{S}$. Biosynthesis and expression of polysialic acid on the neural cell adhesion molecule is predominantly directed by ST8Sia II/STX during in vitro neuronal differentiation. J Biol Chem 1996;271:22058-62

Kolter T, Proia RL, Sandhoff K. Combinatorial ganglioside biosynthesis. J Biol Chem 2002;277:25859-62

Kotani M, Kawashima I, Ozawa H, Terashima T, Tai T. Differential distribution of major gangliosides in rat central nervous system detected by specific monoclonal antibodies. Glycobiology 1993;3:137-46

Kwak DH, Jung KY, Lee YC, Choo YK. Expressional changes of ganglioside GM3 during ovarian maturation and early embryonic development in $\mathrm{db} / \mathrm{db}$ mice. Dev Growth Differ 2003;45:95-102

Kwak DH, Yu K, Kim SM, Lee DH, Jung JU, Seo JW, Kim N, Lee S, Jung KY, You HK, Kim HA, Choo YK. Dynamic changes of gangliosides expression during the differentiation of embryonic and mesenchymal stem cells into neural cells. Exp Mol Med 2006;38:668-76

Leahy $A$, Xiong JW, Kuhnert F, Stuhlmann $H$. Use of developmental marker genes to define temporal and spatial patterns of differentiation during embryoid body formation. $J$ Exp Zool 1999;284:67-81

Lee DH, Koo DB, Ko K, Kim SM, Jung JU, Ryu JS, Jin JW, Yang HJ, Do SI, Jung KY, Choo YK. Effects of daunorubicin on ganglioside expression and neuronal differentiation of mouse embryonic stem cells. Biochem Biophys Res Commun 2007;362:313-8

Lee SY, Kim B, Yoon S, Kim YJ, Liu T, Woo JH, Chwae YJ, Joe EH, Jou I. Phophatidylinositol 4-phospate 5-kinase $a$ is induced in ganglioside-stimulated brain astrocytes and contributes to inflammatory responses. Exp Mol Med 2010;42:662-73

Liour SS, Yu RK. Differential effects of three inhibitors of glycosphingolipid biosynthesis on neuronal differentiation of embryonal carcinoma stem cells. Neurochem Res 2002; 27:1507-12

Liu J, Schoonjans L, Tielens S, Speleman F, Cornelissen M, De Sutter P, Dhont M, Van der Elst J. Culturing in vitro produced blastocysts in sequential media promotes ES cell derivation. Mol Reprod Dev 2006;73:1017-21

Mackie AR, James PS, Ladha S, Jones R. Diffusion barriers in ram and boar sperm plasma membranes: directionality of lipid diffusion across the posterior ring. Biol Reprod

\section{$2001 ; 64: 113-9$}

Martin GR. Isolation of a pluripotent cell line from early mouse embryos cultured in medium conditioned by teratocarcinoma stem cells. Proc Natl Acad Sci USA 1981;78:7634-8

Matsuzaki K, Kato K, Yanagisawa K. A beta polymerization through interaction with membrane gangliosides. Biochim Biophys Acta 2010;1801:868-77

Munro MG. Factors affecting capacitive current diversion with a uterine resectoscope: an in vitro study. J Am Assoc Gynecol Laparosc 2003;10:450-60

Muramatsu T, Muramatsu $\mathrm{H}$. Carbohydrate antigens expressed on stem cells and early embryonic cells. Glycoconj J 2004;21:41-5

Nagai Y, Hoshi M. Sialosphingolipids of sea urchin eggs and spermatozoa showing a characteristic composition for species and gamete. Biochim Biophys Acta 1975;388: 146-51

Nakamura K, Inagaki F, Tamai Y. A novel ganglioside in dogfish brain. Occurrence of a trisialoganglioside with a sialic acid linked to $\mathrm{N}$-acetylgalactosamine. J Biol Chem 1988; 263:9896-900

Ngamukote S, Yanagisawa M, Ariga T, Ando S, Yu RK. Developmental changes of glycosphingolipids and expression of glycogenes in mouse brains. J Neurochem 2007; 103:2327-41

Niwa $\mathrm{H}$. How is pluripotency determined and maintained? Development 2007;134:635-46

Nojiri H, Takaku F, Terui Y, Miura Y, Saito M. Ganglioside GM3: an acidic membrane component that increases during macrophage-like cell differentiation can induce monocytic differentiation of human myeloid and monocytoid leukemic cell lines HL-60 and U937. Proc Natl Acad Sci USA 1986; 83:782-6

Ohmi Y, Tajima O, Ohkawa Y, Mori A, Sugiura Y, Furukawa $\mathrm{K}$. Gangliosides play pivotal roles in the regulation of complement systems and in the maintenance of integrity in nerve tissues. Proc Natl Acad Sci USA 2009;106:22405-10

Okada M, Itoh M, Haraguchi M, Okajima T, Inoue M, Oishi H, Matsuda Y, Iwamoto T, Kawano T, Fukumoto S, Miyazaki H, Furukawa K, Aizawa S. b-series ganglioside deficiency exhibits no definite changes in the neurogenesis and the sensitivity to Fas-mediated apoptosis but impairs regeneration of the lesioned hypoglossal nerve. J Biol Chem 2002;277:1633-6

Osanai T, Watanabe Y, Sanai Y. Glycolipid sialyltransferases are enhanced during neural differentiation of mouse embryonic carcinoma cells, P19. Biochem Biophys Res Commun 1997;241:327-33

Osanai T, Kotani M, Yuen CT, Kato H, Sanai Y, Takeda S. Immunohistochemical and biochemical analyses of GD3, GT1b, and GQ1b gangliosides during neural differentiation of P19 EC cells. FEBS Lett 2003;537:73-8

Proia RL. Glycosphingolipid functions: insights from engineered mouse models. Phil Trans R Soc Lond B Biol Sci 2003;358:879-83 
Rosner H. Significance of gangliosides in neuronal differentiation of neuroblastoma cells and neurite growth in tissue culture. Ann N Y Acad Sci 1998;845:200-14

Schengrund CL. The roles of gangliosides in neural differentiation and repair: a perspective. Brain Res Bull 1990;24: 134-41

Selvaraj V, Asano A, Buttke DE, McElwee JL, Nelson JL, Wolff CA, Merdiushev T, Fornes MW, Cohen AW, Lisanti MP, Rothblat GH, Kopf GS, Travis AJ. Segregation of micronscale membrane sub-domains in live murine sperm. J Cell Physiol 2006;206:636-46

Shadan S, James PS, Howes EA, Jones R. Cholesterol efflux alters lipid raft stability and distribution during capacitation of boar spermatozoa. Biol Reprod 2004;71:253-65

Simons K, Toomre D. Lipid rafts and signal transduction. Nat Rev Mol Cell Biol 2000;1:31-9

Simpson MA, Cross H, Proukakis C, Priestman DA, Neville DC, Reinkensmeier G, Wang $H$, Wiznitzer $M$, Gurtz $K$, Verganelaki A, Pryde A, Patton MA, Dwek RA, Butters TD, Platt FM, Crosby AH. Infantile-onset symptomatic epilepsy syndrome caused by a homozygous loss-of-function mutation of GM3 synthase. Nat Genet 2004;36:1225-9

Smith AG. Embryo-derived stem cells: Of mice and men. Annu Rev Cell Dev Biol 2001;17:435-62

Sridharan R, Tchieu J, Mason MJ, Yachechko R, Kuoy E, Horvath S, Zhou Q, Plath K. Role of the murine reprogramming factors in the induction of pluripotency. Cell 2009;136:364-77

Stern CA, Braverman TR, Tiemeyer M. Molecular identification, tissue distribution and subcellularlocalization of mST3GalV/GM3 synthase. Glycobiology 2000;10:365-374

Svennerholm L. Ganglioside designation. Adv Exp Med Biol 1980;125:11

Takamiya K, Yamamoto A, Furukawa K, Yamashiro S, Shin M, Okada M, Fukumoto S, Haraguchi M, Takeda N, Fujimura K, Sakae M, Kishikawa M, Shiku H, Aizawa S. Mice with disrupted GM2/GD2 synthase gene lack complex gangliosides but exhibit only subtle defects in their nervous system. Proc Natl Acad Sci USA 1996;93:10662-7

Trevino CL, Serrano CJ, Beltran C, Felix R, Darszon A. Identification of mouse trp homologs and lipid rafts from spermatogenic cells and sperm. FEBS Lett 2001;509: 119-25

Uemura K, Sugiyama E, Taketomi T. Effects of an inhibitor of glucosylceramide synthase on glycosphingolipid synthesis and neurite outgrowth in murine neuroblastoma cell lines. J Biochem 1991;110:96-102

Vinson M, Strijbos PJ, Rowles A, Facci L, Moore SE, Simmons DL, Walsh FS. Myelin-associated glycoprotein interacts with ganglioside GT1b. A mechanism for neurite outgrowth inhibition. J Biol Chem 2001;276:20280-5

Yamamoto HA, Mohanan PV. Ganglioside GT1B and melatonin inhibit brain mitochondrial DNA damage and seizures induced by kainic acid in mice. Brain Res 2003; 964:100-6

Yamashita T, Wada R, Sasaki T, Deng C, Bierfreund U, Sandhoff K, Proia RL. A vital role for glycosphingolipid synthesis during development and differentiation. Proc Natl Acad Sci USA 1999;96:9142-7

Yanagisawa M, Yu RK. The expression and functions of glycoconjugates in neural stem cells. Glycobiology 2007; 17:57R-74R

Yu RK, Bieberich E, Xia T, Zeng G. Regulation of ganglioside biosynthesis in the nervous system. J Lipid Res 2004;45: 783-93

Yu RK, Macala LJ, Taki T, Weinfield HM, Yu FS. Developmental changes in ganglioside composition and synthesis in embryonic rat brain. J Neurochem 1988;50:1825-9

Yu RK, Yanagisawa M. Glycosignaling in neural stem cells: involvement of glycoconjugates in signal transduction modulating the neural stem cell fate. J Neurochem 2007;103 Suppl 1:39-46 